\title{
Research on College English Education and Regional Economic Development
}

\author{
Xue $\mathrm{Li}^{*}$ \\ School of Foreign Languages, Dalian Jiaotong University, Dalian, Liaoning 116028, China \\ "Corresponding author. Email: lixue_sherry@djtu.edu.cn
}

\begin{abstract}
With the development of social economy and the strengthening of international communication and cooperation, English has increasingly highlighted its economic value. The development of English education is of great significance to the promotion of regional economy. Based on the relationship between language and economy, this paper expounds the influence of English education on regional economic development, and then analyzes the current situation of college English teaching, and puts forward teaching reform and innovation programs to constantly optimize the curriculum system and clarify teaching objectives. While promoting its own development, it will better serve the construction and development of regional economy. Keywords: College English education, economic development, influence, requirements
\end{abstract}

\section{INTRODUCTION}

As an international language, English is not only a communicative tool. Because of its high-frequency use in communication, English has become more and more valued by all kinds of talents, and its economic value has been highlighted, which is of great significance to the development of the region. Therefore, the ultimate goal of English education is not to acquire and apply English, but to take economic construction and market demand as the orientation, make full use of the rich resources in the region, establish a systematic talent training mode, and cultivate compound talents to realize the double effect of external economic benefit of English education and learning and serve the development of regional economy. As colleges and universities undertake the responsibility of cultivating professional talents for the society, the development of English education will play a positive role and influence on China's regional economy.

\section{THE RELATIONSHIP BETWEEN LANGUAGE AND ECONOMY}

\subsection{The Emergence of Language Economics}

As a discipline combining quantitative research and qualitative analysis to study the relationship between language and economy, the concept of language economics was first proposed by famous American economics professor Jacob Marschak [1], and has been continuously improved by other scholars. Language economics is very important in today's modernization trend, especially in the field of information. Since the 1970s, the subject has been very popular in Europe and
North America. On the basis of absorbing the research results of educational economy and the theory of human capital, qualitative analysis and quantitative research are used to develop and deepen the relationship between language and economy, so as to make the relationship between language and economy more systematic and theoretical. To some extent, if the language meets the needs of the market, it will gain certain economic benefits, which is its market value. The use of the concept of human capital in language research, for one thing, has laid a theoretical foundation for language economics, for another, has also broadened the field of language teaching research.

\subsection{The Value of Language in the Economy}

From the perspective of language economics, language is a kind of human capital, and learning language is an economic investment in human capital. The use of language reflects the economic value. The economic value of language varies from high to low. The use of language has the essence of economics [2]. Generally speaking, the core of the study of language economics is the value and utility, cost and benefit of language in the economy. The economic value of language mainly refers to the actual use status, frequency, language changes, people's evaluation of language and the resulting language policies in the social and economic life in different periods. Driven by the language policy, people get some economic benefits from language learning.

\subsection{Economic Development Determines Language Needs}

Since language and economy are inseparable, the development of economy plays a decisive role in the formation of language's position in human society. 
economy. After in-depth English education, more professional talents can be cultivated to promote foreign exchanges and promote the diversified development of the market. In addition, foreign investment can be further introduced, advanced overseas technologies can be learned, and trade disputes and frictions can be reduced in various tasks, occupations and departmental activities, as well as the relationship between supply and demand [3]. English, a world - class language, is playing an important role in economic development with its unique crossregional transmission and dissemination of scientific and cultural information. This is the inevitable result of the strong economic strength of western developed countries. Therefore, language learning is also a crucial link and means of economic development.

\section{THE INFLUENCE OF ENGLISH EDUCATION ON REGIONAL ECONOMY DEVELOPMENT}

\subsection{Promote the Development of Regional Economy}

With the continuous acceleration of global economic integration today, China is more determined to "go global" strategy. Many mergers or acquisitions of American companies retain their employees. For companies headquartered in the UK and us, English is the main working language. After the acquisition, of course, the problems will include market development and further innovation; however, language is the most obvious and the greatest challenge. Language is not only reflected in the cultural differences of different countries, but also in the meaning of knowledge and technology and management ideas. How to solve these problems? English education is the most direct and effective solution. By giving professional staff professional English training, such as legal English, engineering English, medical English and declaration English, all of these can accelerate the development of regional economy, conducive to China's further integration into the world economic tide.

\subsection{Promote the Economic Development in Foreign Trade}

A country's economy operates in two markets, domestic and foreign. China's economic development largely depends on the international market and trade, which is one of the important characteristics, but the current trade is mostly extensive. The economic operation of foreign markets is mostly in the situation of low added value, poor benefit and trade friction escalation [4]. Take the export to the United States for example, only a superficial understanding of technical regulations, standards, quality recognition system, inspection procedures and procedures and commodity specifications and so on, but not a thorough understanding of its connotation and essence, it is easy to cause varying degrees of losses to China's

\subsection{Promote the Cultural Prosperity of the Region}

By promoting English education in a certain region, the development of economy and trade can be enhanced and the scale of foreign investment can be further expanded. Through the study of English system, we can have a deeper understanding of overseas culture, business rules and trade. The development of foreign trade economy will attract more foreign businessmen, such exchanges and cooperation will gradually permeate other fields, and the culture of this region will also flourish with mutual integration

\section{THE PRESENT SITUATION OF ENGLISH TEACHING IN LOCAL COLLEGES AND UNIVERSITIES}

College English course, as a compulsory course in colleges and universities, is usually offered in the study period of freshmen and sophomores. The main emphasis is on developing students' basic abilities such as English listening, speaking, reading, writing and translating. General education is a basic education for all students to master in the process of learning in the lower grades. However, with the development of foreign language teaching reform in recent years, college English courses aiming at cultivating practical language application ability have become urgent and even inevitable. Relevant data show that in recent years, foreign language talents cultivated by colleges and universities are better in terms of major, but they are still insufficient in terms of practical work [5]. That is to say the practicality of the course has not been effectively demonstrated. Students and graduates have certain basic knowledge, but their application practice is less, so they lack practical application ability. Many graduates find that their English language expression and application skills are poor in job interviews, thus reducing the possibility of job search results. Therefore, the reform and innovation of English teaching must be carried out according to the actual situation of local economic development, so as to effectively improve students' ability of practical application of language and cultivate application-oriented talents for the society. 


\section{REQUIREMENTS OF REGIONAL ECONOMIC DEVELOPMENT ON ENGLISH EDUCATION}

English is no longer simply a symbol of national identity, but contains huge economic effects and values. College English education should be fully aware of this and serve the development of regional economy with the purpose of economic construction and the orientation of market demand.

\subsection{Establish a Reasonable Curriculum System}

In order to better adapt to the development of local regional economy and provide English talents with a higher level, local colleges and universities should actively promote the reform of curriculum system and enhance the cultivation of students' practical application ability. On the one hand, the curriculum should meet the requirements of strengthening students' English foundation and continuously expanding students' accumulation of English foundation through the curriculum arrangement of the lower grades. On the other hand, relevant courses such as business English, foreign trade English, interpretation, etc. are offered for students with specific development goals. This will not only enable students to master the basic knowledge and skills of English, but also provide students with a broader space to improve themselves, get better employment opportunities. It has also created a pool of versatile talent for the region's economic development.

\subsection{Change the Teaching Modes and Methods}

In order to meet the demand of modern economic development for talents, local colleges and universities should change teaching mode and adopt diversified teaching methods according to the characteristics of regional economic development. Teachers should root out the differences of each student and the specific level of English learning, use a variety of practical teaching methods combined with modern teaching mode to increase the cultivation of students' oral ability and listening. Moreover, according to the specific major of the students, improve their necessary professional ability. Making full use of modern teaching methods in terms of the application of English language, a good environment will undoubtedly bring opportunities for students to show themselves [6]. Through social practice, students can recognize the shortcomings in a certain aspect of their language and constantly improve it.

\subsection{Enhance the Cultivation of ESP Professionals}

Colleges and universities must recognize the economic value of English majors themselves, and set up some ESP courses according to the needs of regional economic development, so as to change the previous model of one textbook for all majors and fully reflect the external economic value of language [7]. Let students' English learning and professional knowledge and content closely integrated, rather than separate. Students can be more skilled use of professional knowledge in the future work. In this process, schools should fully consider the actual needs of local economic development and students' own English foundation, formulate a reasonable professional setting and teaching mode, and effectively promote the cultivation of talents.

\subsection{Cultivate Students' Language Communicative Abilities}

At present, English education is mainly aimed at coping with all levels of examinations. Do not understand, do not speak, that is a common problem in English education. To solve this problem, we need to strengthen the cultivation and training of students' comprehensive ability in English education. While emphasizing vocabulary, grammar and reading ability, we should strengthen the training of students' speaking and listening ability. In combination with specific scenes, situational teaching should be strengthened so that students can better understand and get familiar with English that they may use in the future work environment in the process of learning English, so as to put what they have learned into practice and help students to enter the role more quickly after graduation. In addition, colleges and universities should also strengthen the input and cultivation of students' humanistic quality in English education. The course of culture overview of Englishspeaking countries and cross-cultural communication is offered to enable students to understand different cultures, expand their horizons, improve their cross-cultural communication skills, and avoid cultural frictions and conflicts that may appear in the future activities, and better serve the development of regional economy with their professional expertise and skills [8].

\subsection{Strengthen School-Enterprise Cooperation and Set up More Practice Bases}

Practice is very important to improve language skills. The students cultivated by universities will eventually enter the society, but the university education is not closely connected with the society to some extent. College students do not get enough opportunities to study and practice during their study. Lack of practical training makes students to adapt to new roles slowly after entering the workplace and coping ability and flexibility ability is 
poor. Therefore, colleges and universities should combine students' major direction, choose some enterprises and institutions that have demand for English language, and encourage students to participate more and practice more. From the current development situation, English is almost a necessary condition for the development of professionals in all walks of life. In this way, not only can colleges and universities cultivate regional English talents with a definite goal, but also students' learning purpose and pertinence can be strengthened, and the practicability and specificity of English in market application can be enhanced [9]. Moreover, it can also open more channels for students to communicate in English, provide them with more and better practice bases, so that students can have a deeper understanding of the operation of the market, truly combine theory with practice, and truly apply what they have learned. College English majors or majors that pay more attention to the cultivation of English language ability should also strengthen the construction of their own education training base, optimize the allocation of educational resources, strengthen the cooperation and communication between schools and enterprises, so that students can better understand the actual work; At the same time, colleges can also adjust the curriculum and requirements immediately according to the feedback of students, strengthen the pertinence and practicability of students' language learning, expand students' employment opportunities, and promote students to have a comprehensive understanding of the market mechanism.

\section{CONCLUSION}

Regional economic development is closely related to the current college English teaching, so we must objectively and scientifically recognize the great economic value of English and the economic benefits of college English education. Modern college English education should be taking economic construction as the center, guided by market demand and practical, rational allocation of various resources, actively in the region's economic and cultural development is an urgent need to courses, formed to literacy, English language skills, training mode of economic knowledge system and market integration, contributing to the formation of human capital, to realize the external economic benefit of English language learning, to promote the harmonious development of regional economy.

\section{REFERENCES}

[1] Marschak J., The Economics of Language, Behavioral Science, vol. 2, pp.135-140, 1965.

[2] Sun Jianjun, Exploration of Language Economics, Comparative Study of Culture and Innovation, vol. 5, pp. $77+79,2018$.
[3] Guo Shujian, The Development of Language Economics in China- A Review of The Economics of Linguistic Diversity, Heilongjiang Science and Technology Information, vol.5, pp. 293-294, 2017.

[4] Zou Linlin, A Study on the Training Mode of Business English Talents from the Perspective of Language Economics, Journal of Hubei University of Economics (Humanities and Social Sciences Edition), vol. 8, pp. 137-140, 2018.

[5] Wang Limei, Problems and Reflections in College English Teaching from the Perspective of Language Economics, Reading and Writing (Educational Journal), vol. 4, pp7+14, 2019.

[6] Zhou Yun, A Study on College English Smart Teaching Model from the Perspective of Mobile Internet, Modern Educational Technology, vol. 12, pp.79-85, 2016.

[7] Chen Xiao, Cui Yongsheng, ESP Teaching and Eastern Regional Economic Development from the Perspective of Language Economics, Journal of Liaoning Vocational College of Economics, vol.2, pp. 23-25, 2016.

[8] Runen, B.D., The Study of Cross-cultural Competence: Traditions and Contemporary Issues. Internatioanl Journal of International Relations, vol. 89, pp.227-229, 2014.

[9] Cai, W. and Sankaran, G., Promoting Critical Thinking Through an Interdisciplinary Abroad Program, Journal of International Students, vol.5, pp.41-47, 2012. 